\title{
Reflection of Identity through the Use of Bintil Language in Gaya Lentera Muda Community Lampung
}

Komunitas: International Journal of Indonesian Society and Culture 9(1) (2017): 143-149

DOI:10.15294/komunitas.v9i1.4968

(c) 2017 Semarang State University, Indonesia p-ISSN $2086-5465$ | e-ISSN 2460-7320

http://journal.unnes.ac.id/nju/index.php/komunitas

UNNES JOURNALS

\author{
Imelda Oktora ${ }^{1}$, Tina Kartika ${ }^{2}$ \\ 1,2Departement of Communication, Faculty of Social and Political Science, University of Lampung, Indonesia
}

Received: March 2016; Accepted: August 2016; Published: 30 March 2017

\begin{abstract}
Effeminate language reflects effeminate characters and creativity of Gaya Lentera community. Therefore, the effeminate language represents the creative forms of language slang words are fascinating, brief, and simply-recalled. This research found the difference among Gay, Effeminate Men, and LSL [men sex with men] is only at their intonation when they are stating the language. Because through the intonation, they give their intention. There are 42 words examples which are usually used in the community, like: Eke Senandung sama Kanua, Apa kabose, Banjaran, Benyong, Bodrek, Barbie, Pepsi/Kencana wungu, Centong, Capcus, Dese, Duta, Endul/Endang, Gedung, Gilda/Gilingan, Hitachi/Puput melati, Greton/Gretongan, Inang, Eim/ Ember/Um, Jalinan kasih, Jengong, Lagi apose, Lapangan bola, and Tandus. Bintil language among Gay, Transgender and LSL is commonly used in everyday life.
\end{abstract}

\section{Keywords}

language; effeminate men; symbolic interaction

\section{INTRODUCTION}

Gaya Lentera Muda Lampung (Gaylam Lampung) is a community-based organization of Lampung GWL (Gay, Transgender, LSL [men sex with men]) founded on October 9, 2008 in Bandar Lampung. By carrying out the issues of stigma and discrimination against GWL. GWL was established for the empowerment of the GWL community, and involvement in HIV / AIDS prevention, strengthening SOGIE and human rights in Lampung Province.

Currently GAYLAM Lampung has an organizational structure, and the notarial deed. In everyday interaction among their community, they use the language of their community known as Bintil language.
Bintil language can be discussed in the study of language and culture in entholinguistic. Ethnolinguistic as a theoretical concept is part of the branch of linguistic studies that seeks to study the language understanding in a broader context in order to express an understanding of the culture. (Abdullah 2016)

The study of language and culture can also be discussed in their social class. The study of language and culture in the com-

\footnotetext{
Corresponding author

Jln. Prof.Dr.Soemantri Brojonegoro No. 1 Kelurahan

Kedaton Kota Bandar Lampung, Indonesia, 35144 Email

tina.kartika@fisip.unila.ac.id
} 
munity and their social - ethnical phenomena is often associated with the issues surrounding the language styles of certain class to the other Efendi, Agus 2016). Language is a kind of symbol. More than any other symbol, a symbol of more languages show a reality (Syam 2009, p.43; Rawson 2010; Scott 2011; Case 2012; Kuper 2012; Kelly 2011). In social life, there are certain groups that have a particular language as a symbol of group identity which is characterized by distinctive behavior and use of language. Distinctiveness is what differentiates it from other groups (Smith 2012; Gonzalez 2010; Winter 2013; Zimman 2013).

One of them is the Gaylam Lampung Community, the community that accommodates Gay, Transgender and LSL (Men sex with men) in Bandarlampung. Gaylam community Lampung is located at Jl. IN. Panjaitan Gg. Cemara II, behind TK BPK Penabur Bandarlampung.

Language can also be said for generalizing a situation that is typical in certain environments (Kartika 2013, p.33). Likewise, Gaya lentera muda lampung , or often called Gaylam use language to their communities. The language is called the bintil language. People who join this community are also known as bintil. The following is observation data when there is an event in Mall Boemi Kedaton Bandarlampung.

Two gays with the initials J and $\mathrm{P}$ da- ted November 6, 2015, at 15:29 pm."Ih bintil inang, baru nongol dari mana aja nua?[Ih bintil, where have you been?](Inisial J). "Ya maaf sih, eke kan anak sekolahan loh baru polo langsung cus kesindang "[Sorry, I am student, just finished school, rushed here]. (Inisial P) Gay is a designation reserved for men who have sympathy / compassion and romantic touch in men. Women/ mentransgender are those whose bodies are anatomically male sex. Physically they are male but their feelings are women, they have a sense of affection / love of the same sex. Here's a brochure about gaylam.

The existence of the gay community is not only in Lampung Province, but also in East Java, for example. Even the province is said to have Indonesia's biggest transgenders. The community is involved in the prevention of HIV/AIDS. Prevention of HIV/ AIDS through the performances are packaged in a modern ludruk (Maimuna 2014).

Another case the gay existence, for example, a description of the methods a teacher of the students are involved in a research on transgender population, the attitude of transgender populations and how to advocate for this population (Levy 2013). So the existence of gay, lesbian, transgender more and more.

The research uses a qualitative approach with the main data are interviews and observation. Informants are about 10 peop-

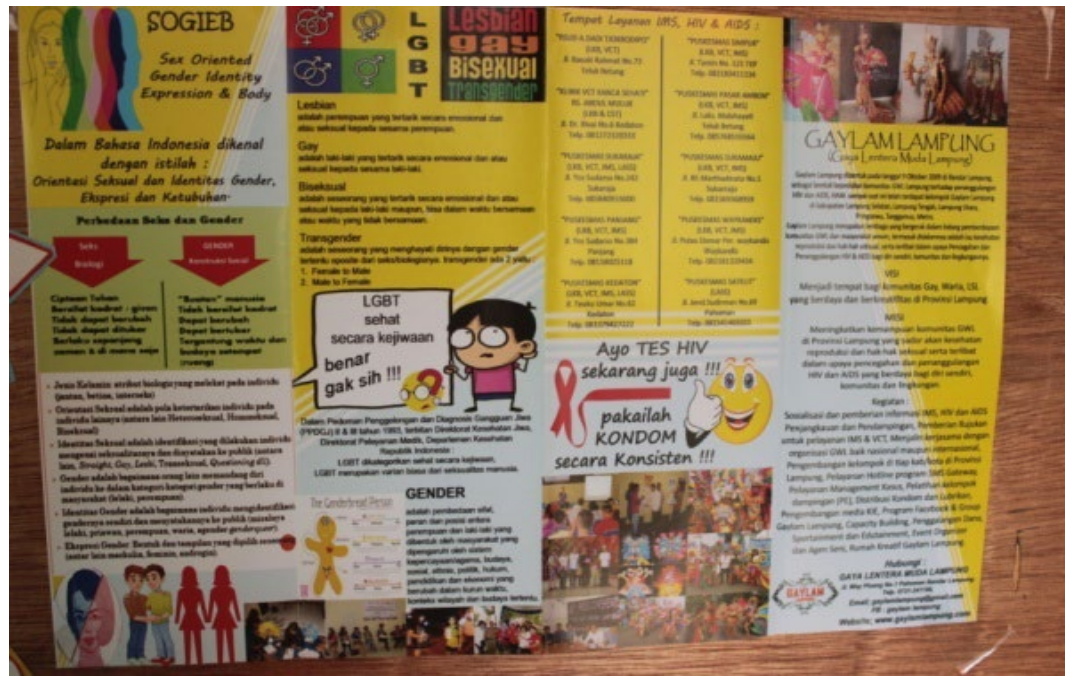

Figure 1: Brochure on gaylam 
le who meet the criteria. They are, with the initials Je, Ps, Ry, Me, Fi, Kn, Al, Rl, Rn and Ra. They are active in the community Gaylam Lampung. Some of them are commercial sex workers (PSK), students, activists, and some work in a company.

The first informan is Je (Gay), 26 years old. Je is an HIV and LGBT activist Now he serves as a "Coordinator of Division 1 " in the Gaylam community Lampung. The second informan is Ps (Gay), aged 17 years, and he is currently still a senior high school student. Ps is a member of Division 3 "Creative Home Gaylam". The third is Ry (Gay), aged 17 years and he is currently still a senior high school student. Ry is a new member in the Gaylam Community. The next informant is Me (Gay), aged 28 years. Me a student at a private college in Bandarlampungwho was also an HIV and LGBT activist. He currently serves as the "Program Manager and Monitoring and Evaluation" in Gaylam Community Lampung. The fifth informant is Fi or commonly called by the name Mn (Transgender), he is 32 years old. He was a sexworker and also an HIV and LGBT activist. The sixth informant is Kn (Transgender), he is senior high school student, and still 18 years old. He was a sexworker and is also a member of the Gaylam Community Lampung. The seventh informant is $\mathrm{Al}$ (Transgender), 20 years old. He is a graduate of SMK who is a, sexworker and also an entrepreneur. He currently serves as a member of Division 1 "Public Relations \& Advocacy". The eighth informant is $\mathrm{Rl}$, he is a student in junior high school in Bandarlampung, and still 15 years old. He is a member of the Gaylam Community Lampung. The ninth informant is Rn (LSL) who is a student at SMK Bandar Lampung and 18 years old. He is a member of the Gaylam Community Lampung. The tenth informant is $\mathrm{Ra}$ (LSL), aged 23 years old and is an employee in Bandar Lampung. He is a member of the Gaylam Community Lampung.

The fourth informant said he was more dominant in the Indonesian language use with family, co-workers and anyone else because he wanted to make his interlocutor comfortable. In the community, he uses bintil language, but still uses Indonesian while discussing the issue at an internal meeting. Here are the results of interviews with the informant:"I still have to always be able to adapt, including the use of language. So when I speak, I have to see the person talking to me. But more often using Indonesian "(interview on August 24, 2015). The fifth informant said that he more dominantly uses Indonesian language in daily life. But in the community, he uses the language of the community and only certain moments uses Indonesian. And when talking about someone else, he uses bintil language so that the conversation is not known by others. Here's the interview:"In daily use, I speak Indonesian, but when talking to friends in the same community, I use bintil language indeed, sometimes there are certain moments that really I should seriously use Indonesian. "(interview on July 9, 2015).

The seventh informant said that when having interaction, he always tries to use Indonesian, because of the nature of different people, one can accept the language of the community, but some cannot. While in the community, informants said that the Indonesian is rarely used. This is shown from the following interview: "we already feel comfortable, use bintil language. The Indonesian is seldom used" (interview on June $17,2015)$.The following table 1 is the example of the community languages/bintil.

\section{The Meaning of Language Practice}

Words in bintil language have special meaning as: "Gedung" which means great in general. Their conception of gedung means too big, but big refers to sex organ of a man. "Bodrex" which means stupid, is known, as a brand for headache remedy, but they use the word to dub himself / others.. "Barbie" is a doll girl and they use it as term for defecate. While urinating they use the word "Pepsi" in the community, and that is a brand of soda drinks. They understand each other's intonation. Especially when they consider themselves to be women. As the following interview: "We bencong, speaking in a spoiled tone. So in my opinion, it depends on the intonation and the intonation of the 
Table 1. Language of The Community/Bintil

\begin{tabular}{|c|c|c|c|}
\hline No & Indonesian language & English language & Bintil \\
\hline 1. & Aku suka sama kamu & I love you & $\begin{array}{l}\text { Eke senandung sama } \\
\text { kanua }\end{array}$ \\
\hline 2. & $\mathrm{Aku} / \mathrm{Kamu}$ & I/you & Eke/Kanua \\
\hline 3. & Apa kabar? & How are you? & Apa kabose? \\
\hline 4. & Baju & Clothes & Banjaran \\
\hline 5 & Banyak & Many/much & Benyong \\
\hline 6. & Bodoh & Stupid & Bodrek \\
\hline 7. & Buang Air Besar & defecate & Barbie \\
\hline 8. & Buang Air Kecil & Pee & Pepsi/kencana wungu \\
\hline 9. & Cantik & Beautiful & Centong \\
\hline 10. & Cepat & fast & Capcus \\
\hline 11. & Dia & He/she & Dese \\
\hline 12. & Duit & Money & Duta \\
\hline 13. & Enak & delicious & Endul/endang \\
\hline 14. & Gede/besar & Big/large & Gedung \\
\hline 15. & Gila & Crazy & Gilda/gilingan \\
\hline 16. & Hitam/Putih & Black/white & Hitachi/Puput melati \\
\hline 17. & Gratis & Free of charge & Gretong/gretongan \\
\hline 18. & Ini & This & Inang \\
\hline 19. & Iya & Yes & Eim/ember/um \\
\hline 20. & Jalan-jalan & Sightseeing/picnic & Jalinan kasih \\
\hline 21. & Jangan & dont & Jengong \\
\hline 22. & Lagi apa? & What are you doing? & Lagi apose? \\
\hline 23. & Lapar & Hungry & Lapangan Bola \\
\hline 24. & Lelaki ganteng & Handsome & Lekong/Laksa cucok \\
\hline 25. & Lama & Long & Lambreta \\
\hline 26. & Lupa & Forget & Lupus \\
\hline 27. & Mahal & Expensive & Maharani/mehong \\
\hline 28. & Makan & Eat & Makarena/mekong \\
\hline 29. & Malas & Lazy & Malay \\
\hline 30. & Mandi & Shower/bath & Mandala \\
\hline 31. & Marah & Angry & Maram/murka/merong \\
\hline & Mau kemana? & Where are you going? & Mawar kemandul? \\
\hline & Mobil/Motor & Car /motorcycle & Mebra/Motorola \\
\hline 34. & Pacaran & Dating & Pecongan \\
\hline & Perempuan & Female & Pere'/pewong/racun \\
\hline & Pulang & Go home & Polo/polda \\
\hline & Pusing & Dizzy & Puyung hai/peniti/puspa \\
\hline & Sepi & Quiet/lonely & Sepiring/sepoi \\
\hline & Ke sini & here & Sindang \\
\hline & Sirik & Envious & Sirsak \\
\hline & Tidak & No & Tinta \\
\hline & Tidur & sleep & Tandus \\
\hline
\end{tabular}

Source: interviews and observational research in 2015 
moment" (interview on August 24, 2015).

Community has a variation of code language, including the accent, the meaning of language, how to speak the so-called communicative repertoire. (Saville, 1986: 51). The Differences in bintil language usage among Gay, Transgender and LSL is only on their intonation in conveying such messages as intonation can give a special meaning to them. The following table 2 is the intonation of the informants.

Table 2. Tone of Voice

\begin{tabular}{lll}
\hline Indonesia Languange & $\begin{array}{c}\text { English lan- } \\
\text { guage }\end{array}$ \\
\hline Gay & $\begin{array}{l}\text { Informan 1 : } \\
\text { Mengayun }\end{array}$ & Informant 1: \\
& Swing \\
& Cempreng & Informant 2: \\
& Informan 3 : & shrill \\
& Lembut \& manja & Soft and spoiled \\
& Informan 4: & Informant 4: \\
& Lembut \& mengayun & Soft and swing- \\
& ing \\
Waria & Informan 5: & Informants 5: \\
& Sengau & Nasal \\
& Informan 6: & Informants 6: \\
& Sengau & Nasal \\
& Informan 7: & Informants 7: \\
& Mengayun & Swing \\
& Informan 8: & Informant 8: \\
& Mengayun & Swing \\
LSL & Informan 9 \&10 & Informant 9 \&10 \\
Tidak ada perubahan & No change of \\
suara & sound \\
\hline
\end{tabular}

Source: interviews and observational research in 2015

\section{Social Interaction}

Two LSL informants in Gaylam Lampung explained that topic of discussion in the community is about SOGIE (sex, orientation, gender identity, expression). Here's the interview: "Topic of discussion in the community is about SOGIE as consistent with the objectives of our community to strengthen the SOGIE so that our members come to know more deeply". (Interview on June 17, 2015). Interaction among their community has always been good, this is done because of the similarities between them. Even to fellow community can comfortably about their social life. Convenience is made closer to each other. This is supported by a research on gays in the city of Samarinda sta- ting that they are sinking to the habits and their behavior because their biological and psychological needs met. (Dwi, 2015).

Loyalty should still be maintained for the continuation of their relationship. Most informants in the study suggests that adherence is an absolute must. Nevertheless not all gay men have commitment to it (Hening 2014). Besides loyalty, individually they also have to control himself, to maintain relationships among couples of a kind. Gays permissive attitudes can be controlled with behavioral self-control. (Dwilaksono et al 2013).

Interacting among them, gays have their own way to tell if someone is gay or not, as the fourth informant experience as follows: "Our fellow community has gaydar: gay radar, that is body language that we already knew that he is a homosexual. And that feeling is $99 \%$ true, it can not be described in words. So now we do not have special features if he is a homosexual. We have community codes of expression, because we are more expressive than men and women. (Interview on August 24, 2015).

The gays, LSL and transgenders often organize the events related to the outside community, as they do in Mal Boemi Kedaton Bandar Lampung, Fashion Week On Novermber 6, 2015. Lampung Fashion Week aims to facilitate creative people to sell and introduce the products and the creativity of her art, such as clothing combined with the kain tenun as a symbol of community pride of Lampung. There are 23 designers coming from Lampung Province and one designer from Jakarta displaying their works. Two designers from Lampung are from the Gaylam Community.

Bintil Language often get carried away when the bintil community use the Indonesian. Nonverbal Bintil Language necessarily follows their behavior. Their behavior is also as a symbol of their bintil. Here are the results of interviews with informants 1:"If I see a handsomemale, usually uses lip movements, such as lip biting side, If I look masculine male, I use a hand gesture, or a glance of the eye, then said "gedung" (big) to friends, he already knew"(Interview on June 
17, 2015).

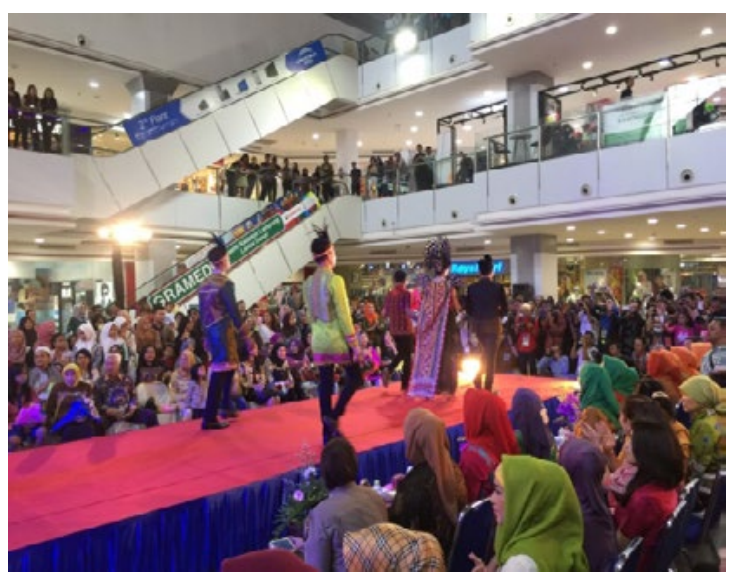

Figure 2. Lampung Fashion Week in Boemi Kedaton Mall BandarLampung

Nonverbal cues in this community, they tend to be more expressive than the men and women who are heterosexual. Their expression through body language show their like or dislike towards others. Informant 2 explained: "Sometimes if we're walking in the mall with friends, we saw the guys, gesturing blink of an eye, we will hold the hair to show that we like the guys "(interview on June 17, 2015). Body languages eg glance, whistled and bitting lip are used to show some affection to men. When they use Indonesian, bintil language are often used. Their behavior as a symbol of bencong. Here's the interview with the informant 1 : "if I see a handsome man, usually biting my lips, moving my hands and glancing, then say: gedung. (Interview on 17-06-2015).

Interaction to people outside the community they also do. They are also members of the community before, such as family and friends. They should maintain good relationships with people of different sex orientations. They are often anxious, especially to their parents. The level of social anxiety of a lesbian, higher than gay. (Rakhmahappin,Yogestri \& Prabowo, Adhyatman.2014)

\section{Appearance}

Gays community is divided into two types, namely masculine and feminine gay. Informant 1 is a masculie gay, his intonation of speech tends to swing to give the sense that he has a sexual orientation, not a heterosexual. Likewise with informant 2, he has the look of masculine but also feminine gay, so- metimes dressed as a sensual women. Informant 1 speaks with shrill intonation giving meaning that he is a "bintil". Informant 3 is a masculine gay but has a soft and spoiled intonation in speaking. This shows that he has male sexual orientation, and not heterosexual. Informant 10 is a masculine gay, but talk softly and swingly. His gait showed that he is a homosexual-oriented.

Differences in the appearance of gays, transgenders and LSL can be seen from their clothes. Gay community tend to wear clothing that is very tight known as "jangkis" clothes and tight jeans. There are several feminine gays but unrecognizable from their clothes. They can be known from their speech, intonation and gait. Their orientation is as same-sex enthusiasts (homosexual). There are three Transgender informants one of whom is a sex worker in Bandarlampung. Women physical characteristics would differentiate it from a gays or LSL. Transgenders also like to dress up and maintain long hair. The sek orientation of transgenders is like the same sex (Homosexual), the difference between transgenders and gay is in appearance.

LSL are men having sex with men because of compulsion. Their sexual orientation has been questioned because they can not choose to be heterosexual (heterosexual), enthusiasts of same-sex (homosexual) or tended to like both (bisexual)? The following is table 3. Showing the appearance of Gay, Transgender and LSL.

Table 3. Appearance of Gay, Transgender and LSL

\begin{tabular}{ll}
\hline & \multicolumn{1}{c}{ Clothes } \\
\hline Gay & $\begin{array}{l}\text { tight clothes “jangkis”, tight } \\
\text { jeans. } \\
\text { Transgender } \\
\text { feminine women's clothes, wear- } \\
\text { ing make-up, long hair and use } \\
\text { women's bags. } \\
\text { As common male, they do not } \\
\text { wear tight clothing. }\end{array}$ \\
\hline
\end{tabular}

Source: interviews and observational research in 2015.

Clothes are an identity within a particular community. As revealed by Berger, as follows: Identity is a phenomenon that emerges from the dialetic between individual and society. Identity types, on the other hand, are social product tout court, relatively stable elements of objective social reality (the degree of stability being of course, so- 
cially determined in its run) (Berger 1979). Gay, transgender and LSL is a unique community that has bintil language and set of rules. The set of rules they create to strengthen them, especially in SOGIE.

\section{CONCLUSION}

The language used in everyday life in the Gaya Lentera Muda Lampung community known as bintil language. There are 42 words identified in the daily life of the community of gaya lentera muda Lampung . Bintil language use among Gay, Transgender and LSL is commonly used in everyday life. Differences in intonation by gays, transgenders and LSL provide its own meaning on the difference. Nonverbal gestures like when seeing men they like: biting lips, winking, waving hand, holding the hair and whistling. And if they see people they do not like: raising eyebrows and whispering with a friend beside him, glancing from top to bottom. Society identifies itself through the use of spoken language. Humans have the freedom to create the language as a communication tool, as long as the language agreed upon by the community. Likewise with gaylam community languages, they have the freedom to create a language to communicate with its members.

\section{REFERENCES}

Abdullah, W., 2016. Javanese Language and Culture in the Expression ofKebo Bule in Surakarta: An Ethnolinguistic Study. Komunitas, International Journal Of Indonesia Society and Culture. 8 (2), pp. 285-294.

Ansara, Y. G., \& Hegarty, P., 2012. Cisgenderism in psychology: Pathologising and misgendering children from 1999 to 2008. Psychology $\mathcal{E}$ Sexuality, 3(2), pp. 137-16o.

Berger, P., \& Lukcman, T., 1979. The Social Construction Of Reality, Treatise in the Sociology of Knowledge. Peguin Books, New York.

Case, K. A., Kanenberg, H., \& Tittsworth, J. 2012. Transgender Inclusion in University Nondiscrimination Statements: Challenging GenderConforming Privilege through Student Activism. Journal of Social Issues, 68(1), pp. 145-161.

Dwi, T. P., 2015. Perilaku dan Realitas Sosial Kehidupan Gay Di Kota Samarinda. eJournal SosiatriSosiologi, 3 (3), pp. 135-150.

Dwilaksono, W., \& Rahardjo, W. 2013. Kontrol Diri dan Perilaku Seksual Permisif Pada Gay. Proceeding PESAT. Vol. 5 Oktober 2013, Bandung, 8-9 Oktober 2013.
Efendi, A., 2016. Pragmatic Study of Discourse Hegemony on the Enactment of Dhalang Trah in Ruwatan Ceremony: A Critical Discourse Analysis Approach. Komunitas, International Journal of Indonesia Society and Culture. 8(2), pp. 199-207

Gonzalez, M., \& McNulty, J., 2010. Achieving competency with transgender youth: School counselors as collaborative advocates. Journal of LGBT Issues in Counseling, 4(3), pp. 176-186.

Hening, P. W., \& Fridari, D. I. G. A., 2014. Dinamika Kesetiaan Pada Kaum Gay. Jurnal Psikologi Udayana, 1(2), pp. 363-371.

Kartika, T., 2013. Komunikasi Antarbudaya (Definisi, Teori dan Aplikasi Penelitian). Lembaga Penelitian Universitas Lampung, BandarLampung.

Kelly, R. J., \& Robinson, G. C., 2011. Disclosure of membership in the lesbian, gay, bisexual, and transgender community by individuals with communication impairments: A preliminary web-based survey. American Journal of SpeechLanguage Pathology, 20(2), pp. 86-94.

Kuper, L. E., Nussbaum, R., \& Mustanski, B., 2012. Exploring the diversity of gender and sexual orientation identities in an online sample of transgender individuals. Journal of sex research, 49(2-3), pp. 244-254.

Levy, D. L., Leedy, G., \& Miller, G., 2013. Preparing Students for Research and for Work with the Transgender Population: Exploring the Results of an Innovative Course Pairing. Journal of Gay $\mathcal{E}$ Lesbian Social Services, 25, pp.306-325

Maimuna, A., 2015. Empowerment of Waria Ludruk Artists in AIDS/HIV Prevention Program. Jurnal Komunitas. 7(1), pp. 79-92.

Rakhmahappin, Y., E Prabowo, A., 2014. Kecemasan Sosial Kaum Homoseksual dan Lesbian. Jurnal Ilmiah Psikologi Terapan, 2(2).

Rawson, K. J., 2010. Accessing transgender//desiring queer (er?) archival logics. Archivaria, 68, pp. 123-140.

Scott, D. A., Belke, S. L., \& Barfield, H. G. 2011. Career development with transgender college students: implications for career and employment counselors. Journal of Employment Counseling, 48(3), pp. 105-113.

Seville, M. T., 1986. The Ethnography of Communivation An Introduction. Basil Blacwell Ltd, New York.

Smith, L. C., Shin, R. Q., \& Officer, L. M., 2012. Moving counseling forward on LGB and transgender issues: Speaking queerly on discourses and microaggressions. The Counseling Psychologist, 40(3), pp. 385-408.

Syam, N. W., 2009. Sosiologi Komunikasi. Humaniora. Bandung

Winter, S., 2013. Language and identity in transgender: gender wars, anatomania, and the thai kathoey. Problematizing Identity: Everyday Struggles in Language, Culture, and Education, pp. 119-136.

Zimman, L., 2013. Hegemonic masculinity and the variability of gay-sounding speech: The perceived sexuality of transgender men. Journal of Language and Sexuality, 2(1), p. 1-39. 